\title{
THE ROLE OF CYCLIN D1 AND VEGF IN RADIOTHERAPY RESPONSE OF ADVANCE STAGE UNDIFFERENTIATED NASOPHARYNGEAL CARCINOMA
}

\author{
Ade Apon Nurhidayat, Afiati, Hermin Aminah Usman, Bethy Suryawathy Hernowo \\ Anatomical Pathology Department, Faculty of Medicine, Universitas Padjadjaran/Hasan Sadikin General Hospital, \\ Bandung, Indonesia
}

\section{ABSTRACT}

\begin{abstract}
Nasopharyngeal carcinoma has a high incidence and mortality rate in Southeast Asia and Indonesia. Radioresistance is a major obstacle to successful treatment of nasopharyngeal carcinoma. DNA repair in the cell cycle and angiogenesis factors affects the response of tumor cells to radiotherapy. Cyclin D1 that functions in the cell cycle process and VEGF as an angiogenesis factor are considered to play a role in the occurrence of radioresistance. The objective of this study is to find the association between immunoexpression of Cyclin D1 and VEGF with radiotherapy response in undifferentiated nasopharyngeal carcinoma. This study used a retrospective case control analysis design, secondary data from medical records of patients diagnosed as undifferentiated nasopharyngeal carcinoma who received complete radiotherapy at the Radiation Oncology Department, Dr. Hasan Sadikin Bandung were taken. There were 44 samples divided into radiosensitive (22 samples) and radioresistant (22 samples) groups. Immunohistochemical examination of Cyclin DI and VEGF was performed on paraffin blocks of patients' biopsy. Data analysis using Chi-Square test ( $p \leq 0.05)$, OR 95\% CI. Cyclin D1 expressed strongly in $86.4 \%$ of the radioresistant group and $59.1 \%$ in the radiosensitive group $(p<0.05)$ and the OR 4,385 (0.993-19.356), VEGF was strongly expressed in $77.3 \%$ of the radioresistant group and $54.5 \%$ in the radiosensitive group ( $p>0.05$ ). As conclusion, there were significant association between Cyclin D1 with radiotherapy respons in undifferentiated nasopharyngeal carcinoma. The stronger immunoexpression of Cyclin D1, the higher likelihood of radioresistancy. VEGF immunoexpression showed no significant association with radiotherapy response.
\end{abstract}

Keywords: Cyclin D1; nasopharyngeal carcinoma; radiotherapy; VEGF

\section{ABSTRAK}

Karsinoma nasofaring merupakan keganasan yang memiliki angka insidensi dan mortalitas yang tinggi di Asia Tenggara dan Indonesia. Radioresistensi menjadi hambatan utama dalam keberhasilan penanganan karsinoma nasofaring. Perbaikan DNA dalam siklus sel dan faktor angiogenesis mempengaruhi respons sel tumor terhadap radioterapi. Cyclin D1 yang berfungsi dalam proses siklus sel dan VEGF sebagai faktor angiogenesis dianggap berperan dalam terjadinya radioresistensi. Penelitian ini bertujuan mencari hubungan antara imunoekspresi Cyclin D1 dan VEGF dengan respons radioterapi pada karsinoma nasofaring tidak berdiferensiasi. Penelitian ini menggunakan desain analisis retrospective case control menggunakan data sekunder dari rekam medis pasien yang didiagnosis sebagai karsinoma nasofaring tidak berdiferensiasi yang mendapat radioterapi lengkap di Departemen Radiasi Onkologi RSUP Dr Hasan Sadikin Bandung. Terdapat 44 sampel yang dibagi menjadi kelompok radiosensitif (22 sampel) dan radioresisten (22 sampel) berdasarkan respons radioterapi. Deteksi ekspresi Cyclin D1 dan VEGF dilakukan dengan pemeriksaan imunohistokimia pada blok paraffin sediaan biopsi nasofaring pasien tersebut. Analisis data menggunakan uji Chi-Square dengan nilai $p \leq 0.05$ dan Odds Rasio CI 95\%. Cyclin D1 terekspresi kuat $86.4 \%$ pada kelompok radioresisten dan 59.1\% pada kelompok radiosensitif dengan $(p<0.05)$ dan Odds Rasio 4.385 (0.99319.356) sedangkan VEGF terekspresi kuat $77.3 \%$ pada kelompok radioresisten dan $54.5 \%$ pada kelompok radiosensitif dengan $(p>0.05)$. Sebagai kesimpulan, terdapat hubungan secara signifikan antara Cyclin Dl dengan respons radioterapi pada karsinoma nasofaring tidak berdiferensiasi. Semakin kuat imunoekspresi Cyclin D1 maka semakin tinggi kemungkinan terjadinya radioresistensi. Imunoekspresi VEGF tidak menunjukkan hubungan yang signifikan dengan respons radioterapi.

Kata kunci: Cyclin D1; karsinoma nasofaring; radioterapi; VEGF

Correspondence: Ade Apon Nurhidayat, Anatomical Pathology Department, Faculty of Medicine, Universitas Padjadjaran/Hasan Sadikin General Hospital, Bandung, Indonesia. Phone: +6285223076909. E-mail: adeapon@gmail.com

pISSN:2355-8393 • eISSN: 2599-056x • doi: http://dx.doi.org/10.20473/fmi.v56i4.23405

- Fol Med Indones. 2020;56:248-253 • Received 4 Jul $2018 \bullet$ Accepted 10 Jan 2019

- Open access under CC-BY-NC-SA license • Available at https://e-journal.unair.ac.id/FMI/ 


\section{INTRODUCTION}

Nasopharyngeal carcinoma (NPC) is a malignancy originating from the nasopharyngeal epithelium (Petersson 2015). This malignancy has a high incidence rate in the East and Southeast Asia region. Based on GLOBOCAN 2012, there are 87,000 new cases emerging each year (Torre et al 2015). In Indonesia, NPC is one of the most common malignancies, ranks 4th in the most cancer incidence after breast cancer, cervical cancer, and lung cancer, makes the most frequent malignancy in the head and neck region. The incidence of NPC in Indonesia is 6.2 per 100,000 populations per year with 13,000 new cases per year. Undifferentiated nasopharyngeal carcinoma is the most common subtype $(90 \%-95 \%)$ found in endemic areas such as in Asia including in Indonesia (Adham et al 2012).

Radiotherapy is the standard choice of undifferentiated nasopharyngeal carcinoma treatment because of its sensitivity to radiotherapy and has difficult anatomical location for surgery (Zhang et al 2013). Radiotherapy has been a chosen treatment since many years and has been performed in various centers in the world. The outcomes of radiotherapy for early stage NPCs are actually quite good with the complete response is about $80 \%-100 \%$. However, the outcomes of radiotherapy for advanced stage NPCs drops significantly with 5-year survival rate less than $40 \%$ due to increased incidence of radioresistance (Yang 2012).

The occurrence of radioresistance is a multistage process involving many genes. Gene fractions that have functions in cell cycle control, apoptosis/antiapoptosis and DNA repair are believed to have an important role in radiation-induced DNA damage. However, the mechanism of radioresistance at the molecular level is not fully understand (Lin 2017, Feng 2010). DNA damage caused by radiation is associated with regulation in the cell cycle (White 2016).

Cyclin D1 is the most type of cyclin that closely related to the genes involved in the cell cycle. Cyclin D1 is a core protein that bound to $\mathrm{CDK} 4 / \mathrm{CDK} 6$ forming the D1-CDK4/6 cyclin complex, which is involved in the phosphorylation of retinoblastoma proteins $(\mathrm{pRb})$ in the G1 and S cell cycle phases and plays an important role in assisting cellular DNA repair (Fu et al 2014)

Radioresistance of tumor cells is also associated with angiogenesis process. Rapid tumor growth can lead to hypoxia so that tumor cells will initiate survival mechanism by activating vascular endothelial growth factor (VEGF), which causes increased vascular proliferation and angiogenesis. The newly formed blood vessels facilitate the provision of oxygen and nutrients to tumor cells. This condition can cause radioresistance on tumor cells. Vascular endothelial growth factor (VEGF) is an angiogenic protein that plays a role in the growth of endothelial cells and tumor blood vessels (Fu et al 2014, Shimura 2011). The aim of this study was to find association between immunoexpression of Cyclin D1 and VEGF with radiotherapy response in undifferentiated nasopharyngeal carcinoma.

\section{MATERIALS AND METHODS}

The sample of this study was using secondary data from medical records of patients diagnosed as undifferentiated nasopharyngeal carcinoma stage IV who received complete radiotherapy at the Department of Radiation Oncology Dr Hasan Sadikin Bandung period 2012-2016. There are 44 samples eligible for inclusion criteria divided into radiosensitive and radioresistance groups based on radiotherapy response according to the agreement of the Criteria in Solid Tumors (RECIST) Response Evaluation. RECIST criteria divide the radiotherapy response into a complete, partial, stable, and progressive response (Padhani \& Ollivier 2001). Complete responses were incorporated into the radiosensitive group, while the partial, stable and progressive responses were incorporated into the radioresistant group. Both radiosensitive and radioresistant groups were consist of 22 samples for each groups. Immunohistochemical examination of Cyclin D1 and VEGF was performed on the paraffin block of patient nasopharyngeal taken from biopsy of the radiosensitive and radioresistant groups. Paraffin block preparations were available from medical records Department of Pathology Hasan Sadikin RSUP Bandung, Indonesia.

Standard procedure of IHC staining was using Cyclin D1 antibody (Clone SP4, Biocare, USA) and VEGF antibody (Clone EP117Y, Biocare, USA). The intensity of Cyclin D1 and VEGF immunoexpressions was assessed on a scale of 0-3 ( 0 , colorless; 1+, weak colored; 2+, medium-colored; $3+$, strongly colored) and the distribution of Cyclin D1 and VEGF immunoexpressions was assessed on a scale of 0-4 (0, negative; $+1,<20 \%$; $2+, 20-50 \%$; $3+, 50-80 \%$; 4+,> $80 \%)$. The immunoexperpression assessment of Cyclin D1 and VEGF was determined based on the number of multiplication intensities and distributions with a weak total of 0-4 and strong histoskor with histoskor 6-12 (Fu SM et al., 2014, Rizzardi A et al., 2012). The diagnosis was established by anatomic pathologist at the Department of Anatomic Pathology, Dr. Hasan Sadikin Hospital, Bandung. 
The data were analyzed using Chi Square test with SPSS 22.0 software for Windows. Significant results are based on statistical calculations when obtained $\mathrm{p} \leq 0.05$.

\section{RESULTS}

Table 1 shows the characteristics of the study subjects consist of age, sex, stage and radiotherapy response. Based on the age group, most cases were found in the 40-60 years age range of 24 cases $(55 \%)$. Based on sex, more men are observed than women with 32 cases (73\%). Most stages were IVB stage with 27 cases $(61.4 \%)$ and stage IV with metastasis to lymph nodes with 36 cases $(82 \%)$.

Table 2 shows the association of Cyclin D1 immunoexpression with radiotherapy response. Statistically it showed significant association $(\mathrm{p}=0.042)$ and Odds Ratio 4.385 (0.993-19.356). In patients with strongly expressed Cyclin D1, there was a possibility for 4,385 times greater radioresistant than patients with weak Cyclin D1 expression. Table 3 shows the association of VEGF immunoexpression with radiotherapy response that showed no significant association $(\mathrm{p}=0.112)$.

\section{DISCUSSION}

In this study, most cases (24 cases) were found in the range 40-60 years old (55\%) with male 3 times more than females. This is consistent with the study of Peterrson et al (2015) stated that in high populations of NPC, the incidence increases after the age of 30 years and reaches peak incidence in the range 40-60 years old, with male 2-3 times more than female. In this study, 36 cases $(82 \%)$ stage IV NPC have metastasized to lymph nodes. This is consistent with previous study that found $70 \%$ of cases of stage IV NPC have metastasized to lymph nodes (Xuan et al 2013).

Table 1. Characteristics of subjects based on radiotherapy response

\begin{tabular}{|c|c|c|}
\hline \multirow[b]{2}{*}{ Variable } & \multicolumn{2}{|c|}{ Radiotherapy Response } \\
\hline & $\begin{array}{c}\text { Sensitive } \\
\mathrm{N}=22\end{array}$ & $\begin{array}{c}\text { Resistant } \\
\mathrm{N}=22\end{array}$ \\
\hline \multicolumn{3}{|l|}{ Age } \\
\hline$<40$ years & $6(27.3 \%)$ & $731.8 \%)$ \\
\hline $40-60$ years & $11(50.0 \%)$ & $13(59.1 \%)$ \\
\hline$>60$ years & $5(22.7 \%)$ & $2(9.1 \%)$ \\
\hline \multicolumn{3}{|l|}{ Sex } \\
\hline Man & $14(63.6 \%)$ & $18(81.8 \%)$ \\
\hline Woman & $8(36.4 \%)$ & $4(18.2 \%)$ \\
\hline \multicolumn{3}{|l|}{ Staging } \\
\hline \multicolumn{3}{|l|}{ IVA } \\
\hline T4N0M0 & $5(22.7 \%)$ & $3(13.6 \%)$ \\
\hline T4N1-2M0 & $5(22.7 \%)$ & $4(18.2 \%)$ \\
\hline IVB & & \\
\hline $\begin{array}{l}\text { Any T N3 M0 } \\
\text { IVC }\end{array}$ & $12(54.5 \%)$ & $15(68.2 \%)$ \\
\hline Any T Any N M1 & $0(0.0 \%)$ & $0(0.0 \%)$ \\
\hline
\end{tabular}

Table 2. Association of imunnoexpression cyclin d1 with radiotherapy response

\begin{tabular}{lcccc}
\hline \multirow{1}{*}{ Variable } & \multicolumn{2}{c}{ Radiotherapy Response } & & \\
& Sensitive & Resistant & OR (CI95\%) & P Value \\
& $\mathrm{N}=22$ & $\mathrm{~N}=22$ & & $4.385(0.993-$ \\
\hline Cyclin D1 & & & $19.356)$ & $0.042^{* *}$ \\
Immunoexpression & $9(40.9 \%)$ & $3(13.6 \%)$ & & \\
Weak (0-4) & $13(59.1 \%)$ & $19(86.4 \%)$ & \\
Strong (6-12) & & & \\
\hline
\end{tabular}


Table 3. Association of VEGF imunnoexpression with radiotherapy response

\begin{tabular}{|c|c|c|c|c|}
\hline \multirow[b]{2}{*}{ Variable } & \multicolumn{2}{|c|}{ Radiotherapy Response } & \multirow[b]{2}{*}{ OR (CI95\%) } & \multirow[b]{2}{*}{ P Valu } \\
\hline & $\begin{array}{c}\text { Sensitive } \\
\mathrm{N}=22\end{array}$ & $\begin{array}{c}\text { Resistant } \\
\mathrm{N}=22\end{array}$ & & \\
\hline VEGF & & & 2.833 & 0.112 \\
\hline Imunnoexpression & & & $\begin{array}{l}(0.770- \\
10.430)\end{array}$ & \\
\hline Weak (0-4) & $10(45.5 \%)$ & $5(22.7 \%)$ & & \\
\hline Strong (6-12) & $12(54.5 \%)$ & $17(77.3 \%)$ & & \\
\hline
\end{tabular}
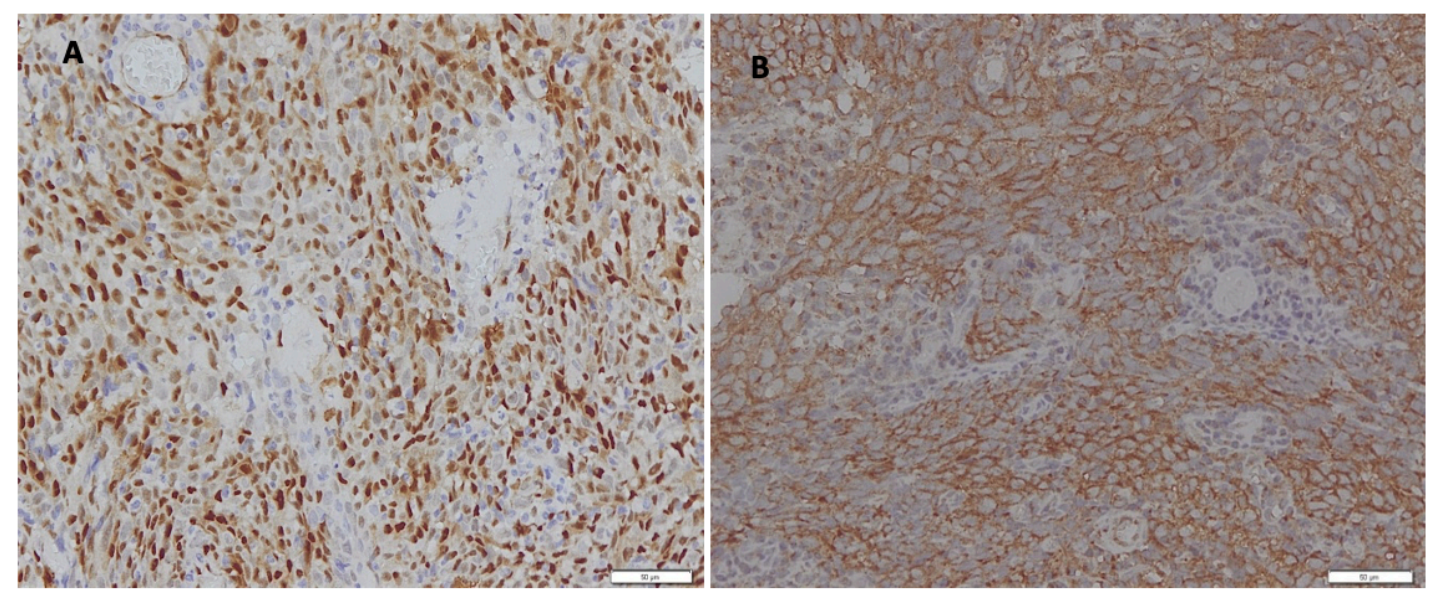

Fig. 1. Cyclin D1 and VEGF immunoexpression of Nasopharyngeal Carcinoma (A) Cyclin D1 strong expression, (B) VEGF strong expression (400X magnification).

The Cyclin D1 immunoexperpression of all samples in this study showed positive expression, 32 cases $(72.7 \%)$ show strong expression and 12 cases (27.3\%) show weak expression. The comparison of Cyclin D1 expression in the radiosensitive group and the radioresitant group showed significant result $(p=0.042)$ with Odds Ratio 4.385 (0.993-19.356). This suggests that there was a significant association between Cyclin D1 expression and radiotherapy response. Patients with strong Cyclin D1 expression had the possibility of radiotherapy resistance of 4,385 times (0.993-19.356) compared with patients with weak Cyclin D1 expression. This is likely due to DNA damage by radiation activating the AKT/Cyclin D1/CDK4 pathway. This AKT pathway facilitates the repair of DNA in tumor cells to provide tumor cell survival and subsequently contributes to radioresistance (Shimura 2012, Shimura 2011).

The results of this study are consistent with previous studies. There showed significant differences between strong Cyclin D1 expression in the sensitive radiotherapy response group and in the insensitive group $(p<0.05)$. Patients with weak Cyclin D1 expression are more sensitive to radiation. The strongly expressed Cyclin D1 causes G1-S phase shortening in the cell cycle results in uncontrolled cell proliferation and promotes tumor cell growth. Radiation-induced DNA damage can also activates Cyclin D1 to assist the process of DNA repair, thus increasing tumor cell survival and results in resistance to radiotherapy (Fu et al 2014). Cyclin D1 depletion in HeLa cervical carcinoma cells and H2009 lung cancer cells significantly increases the sensitivity of cancer cells to radiation. This suggests Cyclin D1 may play a role in repairing damaged DNA (Jirawatnotai 2011). Cyclin D1 is an important key to cell cycle progression through G1 phase associated with poor radiation response. In other study, decreased Cyclin D1 in esophageal cancer can slow down tumor cell growth and can reduce the DNA repair capacity of tumor cells. Inhibition of Cyclin D1 can prevent DNA repair of tumor cells ( $\mathrm{Su} 2015$ ).

In this study, all VEGF immunoxpression showed positive expression, 29 cases (65.9\%) show strong expression and 15 cases (34.1\%) show weak expression. 
The results of this study show no significant association between VEGF immunoexpression with radiotherapy response $(\mathrm{p}=0.117)$. This may be caused by the hypoxic state that induces HIFa and results in radioresistance occurring through multiple pathways. These pathways are HIFla/VEGF pathways, HIFa/CXCL12 pathways, $\mathrm{HIFa}$ /Transforming Growth Factor b (TGFb pathways and $\mathrm{HIFa} / \mathrm{TGFb} /$ integrin pathways. $\mathrm{HIFa} / \mathrm{VEGF}$ pathways and $\mathrm{HIFa} / \mathrm{CXCL} 12$ pathways induce angiogenesis and vasculogenesis. The $\mathrm{HIFa}$ /Transforming Growth Factor b (TGFb) pathway induces angiogenesis and maintains vascular homeostasis, whereas $\mathrm{HIFa} / \mathrm{TGFb}$ /integrin pathway may cause endothelial cell survival against radiation effects (Barker 2015). In this study, another possible factor that induces angiogenesis, other than VEGF as mentioned above, is more dominant in causing the occurrence of radioresistance. Thus, this study found unsignifficant association between VEGF with radiotherapy response.

It was explained that in nasopharyngeal carcinoma, the oxygen factor alone is not sufficient to predict radiosensitivity, there are many other biological factors that involve in radiosensitivity (Hendarsih et al 2015). Moreover, the amount of angiogenic factors influence the pathway of radioresistance. Tumor cells with a few angiogenic factors will become radioresistence via hypoxic pathways, whereas tumor cells that have much of angiogenic factors will become radioresistance through intrinsic pathways and ischemic factors. These mechanisms can cause undetectable VEGF expression in radioresistance (Homer \& Stafford 2001).

The factors mentioned above may induce the occurrence of nasopharyngeal carcinoma metastases into the lymph nodes (Xuan et al 2013, Qiao et al 2016, Wu et al 2017). CXCL12 expression is increased in cases of nasopharyngeal carcinoma with lymph node metastasis compared with cases without metastasis to lymph nodes. CXCL12 which forms the bond with CXCR4/CXCR7 may affect migration, invasion and survival of nasopharyngeal carcinoma cells (Qiao et al 2016). $\mathrm{TGFb}$ may serve as a protooncogen at an advanced stage by stimulating angiogenesis and inducing epithelial mesenchymal tumors (EMT) that contribute to tumor cell invasion and metastasis (Wu et al 2017). Expression of integrin av is significantly associated with lymph node metastasis in nasopharyngeal carcinoma. Integrin is a molecule that involve in the process of invasion, metastasis, angiogenesis and tumor cell survival (Xuan et al 2013). In this study, $82 \%$ of cases have metastasized to lymph nodes. This suggests that all factors mentioned above may be more dominant than VEGF in causing radioresistence, thus in this study there was no significant association between VEGF and radiotherapy response.

\section{CONCLUSION}

There were significant association between Cyclin D1 with radiotherapy response in undifferentiated nasopharyngeal carcinoma. The stronger immunoexpression of Cyclin D1, the higher likelihood of radioresistancy. VEGF immunoexpression showed no significant association with radiotherapy response.

\section{ACKNOWLEDGMENT}

Major thanks to Sri Mulyati, dr and Fauzan Ali Zainal Abidin, dr., for comments, corrections and suggestions on this article.

\section{REFERENCES}

Adham M, Kurniawan A, Muhtadi A (2012). Nasopharyngeal Carcinoma in Indonesia: epidemiology, incidence, signs, and symptoms at presentation. Chin J Cancer 31, 185-196

Barker HE, Paget JTE, Khan A, Harrington KJ (2015). The tumour microenvironment after radiotherapy: mechanisms of resistance and recurrence. Nature 15, 409-425

Feng XP, Yi H, Li MY, et al (2010). Identification of biomarkers for predicting nasopharyngeal carcinoma response to radiotherapy by proteomics. Cancer Res, 3450-3462

Fu SM, Xu FM, Lin SM, Liang Z, Cai JH (2014). Association of cyclin D1 and survivin expression with sensitivity to radiotherapy in patients with nasopharyngeal carcinoma. Genet. Mol. Res 13, 3502-3509

Hendarsih E, Oehadian A, Sumantri R, Supandiman I, Hernowo BS (2015). Ekspresi vascular endothelial growth factor dan ekspresi tissue factor berdasarkan respons terapi kemoradiasi cisplatin pada penderita karsinoma nasofaring stadium lanjut. MKB, 49-54.

Homer JJ, Greenman J, Stafford ND (2001). The expression of vascular endothelial growth factor (VEGF) and VEGF-C in early laryngeal cancer: relationship with radioresistance. Clin. Otolaryngol 26, 498-504

Jirawatnotai S, Hu Y, Michowski W et al (2011). A function for cyclin D1 in DNA repair uncovered by protein interactome analyses in human cancers. Nature 474, 230-233

Lin H, Chen ZT, Zhu XD, et al (2017). Serum CD166: A novel biomarker for predicting nasopharyngeal carcinoma response to radiotherapy. Oncotarget 110 
Padhani AR, Ollivier L (2001). The RECIST criteria: implications for diagnostic radiologists. The British Journal of Radiology 74, 983-986

Petersson, F (2015). Nasopharyngealcarcinoma: A review. Seminars in Diagnostic Pathology, 1-20

Qiao N, Wang L, Wang T, Li H (2016). Inflammatory CXCL12-CXCR4/CXCR7 axis mediates G-protein signaling pathway to influence the invasion and migration of nasopharyngeal carcinoma cells. Tumor Biol 37, 8169-8179

Rizzardi A, Johnson A, Vogel R, et al (2012). Quantitative comparison of immunohistochemical staining measured by digital image analysis versus pathologist visual scoring. Diagnostic Pathology 7, 42

Shimura T (2011). Acquired radioresistance of cancer and the AKT/GSK3ß/cyclinD1 overexpression cycle. J. Radiat. Res 52, 539-544

Shimura T (2012). Activation of the AKT/cyclin $\mathrm{D} 1 / \mathrm{Cdk} 4$ survival signaling pathway in radioresistant cancer stem cells. Oncogenesis, 1-9

Su H, Jin X, Shen L, et al (2015). Inhibition of cyclin D1 enhances sensitivity to radiotherapy and reverses epithelial to mesenchymal transition for esophageal cancer cells. Tumor Biol, 1-9

Torre L, Bray F, Siegel R, et al (2015). Global Cancer Statistics, 2012. CA CANCER J CLIN 65, 87-108

White L (2016). Predictive biomarkers of cellular radiosensitivity for clinical radiotherapy treatment. A Doctoral Thesis. Dublin Institute of Technology

Wu Y, Shen Z, Wang K, et al (2017). High FMNL3 expression promotes nasopharyngeal carcinoma cell metastasis: role in TGF- $\beta 1$-induced epithelia-tomesenchymal transition. Scientific Report 7, 1-14

Xuan SH, Zhou YG, Pan JQ, Zhu W, Xu P (2013). Overexpression of integrin av in the human nasopharyngeal carcinoma associated with metastasis and progression. Cancer Biomarkers 13, 323-328

Yang S, Chen J, Guo Y, et al (2012). Identification of prognostic biomarkers for response to radiotherapy by DNA microarray in nasopharyngeal carcinoma patients. Inter. Jour. Oncol 40, 1590-100

Zhang L, Chen QY, Liu H, Tang LQ, Mai HQ (2013). Emerging treatment options for nasopharyngeal carcinoma. Drug Design, Development and Therapy $7,37-52$ 